\title{
Po pierwsze nie metaforyzuj! 0 tropach demencji
}

\author{
Hanna Serkowska
}

TEKSTY DRUGIE 2021, NR 1, S. 59-80

DOI: 10.18318/td.2021.1.4 | ORCID: 0000-0001-6150-6185

Kiedy chorujemy, musimy opowiadać o chorobie, stwarzać jej narrację i jej metafory.

O. Sacks ${ }^{1}$

$\mathbf{N}$

Tiniejsze rozważania poświęcone są vexata quaestio związków choroby i metafory, swego czasu poddanemu radykalnej krytyce przez Susan Sontag, a następnie przez wielu komentowanych ${ }^{2}$. W szczególności zaś jednemu aspektowi eseju Choroba jako metafora ${ }^{3}$ jeszcze przez badaczy nieporuszonemu, tj. wzajemnej zamienności biegunów rzeczy pseudonimowanej i jej figur, której Sontag być może świadomie nie podkreśla, a w każdym

1 O. Sacks Wstęp, w: A. Broyard Upojony chorobq. Zapiski o życiu iśmierci, przeł. A. Nowakowska, Czarne, Wołowiec 2010, s. 9.

2 Komentarze te przytacza ostatnio M. Ładoń. Sama wikła się w polemikęz esejem Sontag, przekonuje, że wykluczenie metafor uniemożliwia zrozumienie, i pyta, czy posługując się metaforami, zbliżamy się do choroby czy się od niej oddalamy; por. tejże Choroba jako literatura. Studia maladyczne, Wydawnictwo Naukowe Śląsk, Katowice 2019, S. 2-24.

3 S. Sontag Choroba jako metafora. AIDS i jego metafory, przeł. J. Anders, Karakter, Kraków 2016. 
razie sama nie przestrzega stałego biegunowego przyporządkowania. Choroba jako metafora, a właściwie jako domena źródłowa metafory (np. korupcja to toczący społeczeństwo rak), i metafory choroby reprezentujące domenę docelową metafory (np. opisywanie procesów chorobowych i terapeutycznych przez odniesienia do pola semantycznego działań militarnych - takie mówienie o chorobie i cierpieniu stało się głównym powodem sprzeciwu Amerykanki) z punktu widzenia krytyki zapoczątkowanej przez Sontag są jednym i tym samym. Z perspektywy lingwistycznej (kognitywnej teorii metafory) zamiana domen, pełniących przecież odmienne funkcje - w naszym przypadku domeną metafory jest choroba - nie jest bez znaczenia. Zastanowimy się, jakie implikacje pociąga za sobą wzajemna wymienność tych biegunów, na przykładzie tropów powiązanych z chorobą w tekstach kultury ostatnich lat. Studium przypadku będzie choroba otępienna. To decyzja o tyle uzasadniona, że demencja, a zwłaszcza najczęstsza jej odmiana, alzheimer ${ }^{4}$, ma obecnie swój czas, bo każda choroba ma swój czas i każdy czas mają swoją chorobę siejącą panikę, zwłaszcza jeśli łączy się ją z zachowaniami nieakceptowanymi z punktu widzenia obowiązującego sytemu wartości. Jak wynika ze statystyk, naszym nowym cesarzem chorób, silnie oddziałującym na wyobraźnię i powszechnie odbieranym jako najstraszniejszy wyrok w epoce hiperkognitywnej, tzn. najwyżej ceniącej przymioty racjonalnej, samodzielnej i samowystarczalnej jednostki - jest właśnie demencja ${ }^{5}$. Od starożytności choroba jawi się w kulturze jako zło powszechne: nie jako choroba sama w sobie, lecz swoista metachoroba, choroba chorób. Jako kwintesencja, summa wielu bolączek, jako Zło zagrażające bytowi ${ }^{6}$. Nie dziwi zatem użycie choroby uważanej obecnie za najpotworniejszą z patologii jako

4 Podobnie jak autorzy analizowanych tekstów nie przestrzegam podziału na fazy choroby mogące różnić się u poszczególnych chorych ani na rodzaje otępień zwanych często łącznie Alzheimer's Disease and Related Dementias.

5 Narrator Flavia Pagana zastanawia się, jak wobec wieszczonej epidemii alzheimera zachowa się ludzkość. Nie cenimy tego, co w naszym świecie nie jest nastawione na wydajność, zysk, produktywność i konsumpcję, więc "czy starcy będą otaczani opieką jak Królowa pszczół, czy cmentarze zamienią się w wysypiska biologicznych odpadów?", F. Pagano Perdutamente, Giunti, Firenze 2013, s. 66-67.

6 Zob. R. Brok Sickness in the Body Politic. Medical Imagery in the Greek Polis, w: Death and Disease in the Ancient City, ed. V.M. Hope, E. Marshall, Routledge, London-New York 2000, s. 24-33; S. Givone Metafisica della peste. Colpa e destino, Einaudi, Torino 2012; G. Carillo Quando il male si fa spazio. Patologia e politica in Orestea, w: La malattia come metafora nelle letterature dell'Occidente, ed. S. Manferlotti, Liguori, Napoli 2014, s. 1-17, tu s. 14. 
metafory kulturowej czegoś od choroby innego, na co choroba przenosi swój ładunek zła. W drugiej części artykułu przestawię pola takich odniesień, by zastanowić się nad skutkami metaforycznego użycia demencji w funkcji domeny źródłowej. O chorobie otępiennej będzie także mowa jako o domenie docelowej metafory, a to sytuacja z pierwszą nietożsama.

\section{Choroba rozluźnia ziemię (językowej) wyobraźni}

Dla większości osób doświadczenie choroby nie jest czymś obcym. Nawet jeśli używamy naszego ciała w sposób bezwiedny, a przez to bezwzględny, co jest możliwe dlatego, że ciało podąża posłusznie za narzucaną mu wolą, któregoś dnia spostrzegamy, że ciało istnieje jakby niezależnie od naszej woli, a jego organy odmawiają umysłowi posłuszeństwa. Świat materii okazuje wówczas swoje prawdziwe oblicze, a człowiek czasem, jak pisał Balzak w Jaszczurze, zniża się do poziomu gnuśnych żyjątek, które pleśnieją w głębi lasów, podobne do szczątków roślinnych? ${ }^{7}$. Skoro pod wpływem choroby (lub procesów starzenia) zmuszeni jesteśmy oddać się ciału we władanie, zamiast, jak wcześniej, panować nad nim, to czy płynie z tego chociaż jakiś pożytek? Blisko sto lat temu Virginia Woolf pisała, że ból i choroba na powrót łączą ciało z głową, że ten, kto odczuwa chroniczny ból, nie może dłużej ciała ignorować. I jeśli ból coś rozjaśnia, to to, czego sama głowa nie byłaby w stanie pojąć. Woolf dziwiło przeto, że nikt wcześniej nie spisał „powszedniego dramatu ciała”, że ludzie „piszą o poczynaniach umysłu [...]. Ukazują umysł, który, zamknięty w wieży filozofa, ignoruje ciało"8. W podobnym duchu odczytujemy przełożone na język filozofii rozważania Emila Ciorana wokół tego, kto nie miewa się wcale, dopóki miewa się dobrze, bo aby istnieć, trzeba poznać rzeczywistość choroby9. Podobnie jak Kafka, który mawiał, że sensem

7 H. de Balzac /aszczur, przeł. T. Boy-Żeleński, Książka i Wiedza, Warszawa 1949, s. 114.

8 V. Woolf O chorowaniu, przeł. M. Heydel, wstęp H. Lee, Czarne, Wołowiec, 2010, s. 30 i 31.

9 E. Cioran O chorobie, w: tegoż Upadek w czas, przeł. I. Kania, Aletheia, Warszawa 2008, s. 117. W Wyznania i anatemy Cioran napisze, że doskonale zdrowi nie są realni, tzn. nie poznali rzeczywistości ciała, a nie ma nic bardziej rzeczywistego od choroby (przeł. K. Jarosz, Aletheia, Warszawa 2018, s. 47). W eseju Sontag znajdziemy wyimek z Fragmentów Novalisa o tym, że o ile zdrowie może interesować tylko naukę " "rzeczą naprawdę ciekawą jest choroba, która należy do indywidualizacji", por. tejże Choroba jako metafora, s. 32. H.-G. Gadamer idzie dalej, twierdząc, że zdrowie to samozapomnienie (nie wymaga naszego świadomego udziału tak samo jak oddychanie, trawienie czy bicie serca), a choroba jest tego stanu zakłóceniem; por. tegoż O skrytości zdrowia, przeł. A. Przyłębski, Media Rodzina, Poznań 2011, s. 134. 
życia jest to, że się kończy, Cioran powiada, że choroba pozwala nam dostrzec istotę zdrowia w szczególności i bytu w ogóle. Daje większy wgląd w to, jak się rzeczy mają: „we wszystkich tych chorobach - znowu Woolf - najlepsze jest to, że rozluźniają ziemię wokół korzeni, wprowadzają zmiany. Ludzie zaczynają wyrażać uczucia"10.

Kiedy nasz ignorujący ciało umysł zostanie zetknięty z czymś nieznanym i niewyobrażalnym, wcześniej niedoświadczonym, podejmuje wysiłek zrozumienia i wyrażenia tego zjawiska. Przekładając chorobę na tekst, zamieniając ją w znak, poddając symbolizacji, zyskujemy bogate instrumentarium, zróżnicowane pod względem stylistycznym, genologicznym, poetologicznym. Można o chorobie pisać autobiograficznie i uobecniać cierpienie. Można też próbować chorobę oddalać, obiektywizować czy wręcz "medykalizować”. Można ją nazywać po imieniu bądź pseudonimować, poddawać się jej, ulegać, oswajać ją albo z niej drwić. Czasami jedna, a niekiedy inna strategia okazuje się właściwsza dla zwykłego zakomunikowania, wyrażenia czy innego użycia cierpienia w jakimś estetycznym lub pozaestetycznym celu ${ }^{11}$. Teksty należące do kategorii narracji chorobowych są bowiem zorganizowane tak jak wszystkie inne odmiany tematyczne tekstu: raz wokół funkcji informacyjnej, kiedy indziej przeważają funkcje ekspresyjne (obejmujące także funkcje autokreacyjne podmiotu opowiadającego swoje doświadczenie choroby), w jeszcze innych przypadkach aktywna może być w szczególności, samodzielnie lub w połączeniu z pierwszymi dwoma, funkcja operacyjna, perswazyjna. Jakkolwiek w dalszym ciągu zastanawiać się będziemy nad wąsko zakreśloną grupą tekstów - należących do odmiany narracji o chorobach otępiennych - nie sposób pominąć niezwykle zróżnicowanego zakresu motywacji i dążeń przyświecających pisarskiej pracy w ogóle, zwłaszcza w odniesieniu do doświadczenia choroby. Pisząc, jak twierdził Aleksander Wat, dokonujemy "nadkompensacji” albo ucieczki, zaspokajamy potrzebę przeglądania się w lustrze lub sublimujemy stłumione popędy. Pisanie można traktować jako kompromis, jako modlitwę, jako powroty albo jako sposób ot, przeżycia życia. Może być poszukiwaniem

10 V. Woolf O chorowaniu, s. 10.

W narracjach maladycznych (pojęcie wprowadzone przez K. Szewczyka w Dobro, zło i medycyna. Filozoficzne podstawy bioetyki kulturowej, PWN, Warszawa-Łódź 2001, s. 334), określanych także jako patografie (termin pathography wprowadziła A. Hunsaker Hawkins w: Reconstructing Illness: Studies in Pathography, Purdue UP., West Lafayette, Indiana 1993), często wiedza i samowiedza podmiotu wyłaniają się w akcie twórczym, pisanie jest bowiem niekończącym się projektem samorealizacji, samoidentyfikacji i samorozumienia. 
straconego czasu, utraconego raju, chęcią zatrzymania czasu albo walką ze swoim czasem, wreszcie - wyprowadzeniem z siebie śmierci albo jej wprowadzeniem $^{12}$. Taka niejednoznaczność pisarskich postaw dodatkowo wzbogaca, komplikuje, ale i podważa radykalnie sformułowane tezy Sontag (deklarującej wymiar wyłącznie komunikacyjny tekstu ${ }^{13}$, a w istocie usiłującej zapanować nad funkcją operacyjną języka), które wypada tu pokrótce przypomnieć.

\section{Dla kogo metafory choroby?}

Choć Sontag pisze z serca własnej onkologicznej katastrofy, unika pierwszoosobowych nawiązań. Interesuje ją wyłącznie, by tak rzec, widok cudzego cierpienia. To innym chorym autorka Przeciw interpretacji pragnie dodać odwagi do podjęcia terapii, to w ich imieniu opowiada się przeciwko szkodliwej mocy mitów i metafor. Mówienie rzekomo w imieniu innych chorych wydaje się okolicznością nie bez znaczenia, zdając relację z własnego cierpienia, rozpaczy i lęku, trudniej bowiem obejść się bez tropów, peryfraz i przenośni. Co więcej - przed czym ironicznie przestrzegał Cioran - płochliwemu czytelnikowi może wydać się, że opowiadamy innym o swojej chorobie w nadziei, że ich tym własnym cierpieniem zarazimy ${ }^{14}$.

Do kogo i dla kogo zatem piszemy, pisząc o chorobie? Jerzy Pilch w rozmowie o swoich chorobowych arcydziełach daje wyraz wątpliwościom dotyczącym odbiorcy chorobowego zapisu. Mówi, że skoro zasadą opowieści jest utożsamienie z bohaterem, opowieści o chorobach, nawet jeśli pełne metafor, raczej nie są dla zdrowych: „Nie mówię, że Czarodziejska góra jest tylko dla gruźlików, ale nie wykluczam, że gruźlik, bywalec jakichś sanatoriów, czyta to pełniej"15. Trzeba więc, niezależnie od tego, czy nazwiemy

A. Wat Dziennik bez samogłosek, Czytelnik, Warszawa 2001, s. 49.

W powstałym dziesięć lat później eseju AIDS $i$ jego metafory autorka stwierdza, że pisząc tekst Choroba jako metafora, kierowała się wyłącznie kryterium użyteczności, przekonana, że „forma opowieści byłaby mniej przydatna niż przekazanie pewnych przemyśleń. Po przyjemność narracji mogłam sięgnąć do innych pisarzy" (s. 94). Oznaczałoby to - a przecież tak nie jest - że celem ataku Sontag jest język komunikacji codziennej, a nie literacki.

E. Cioran O chorobie, s. 118.

Pókiśmy nieślepi, wywiad K. Kubisiowskiej, "Tygodnik Powszechny” 2012 nr 21, s. 24. A. Broyard planuje napisać o swojej chorobie, bo "choć ludziom potrzebne są książki takie jak The Transit of Venus, które pozwalają im zapomnieć, łakną oni także literatury o cierpieniu", tegoż Upojony chorobq, s. 26. 
naszą relację esejem, wspomnieniami, nowelą czy dziennikiem, dokonać rozrachunku z odmienną egzystencjalną sytuacją, dokładnie rozeznać nową (czy na pewno ułomną ${ }^{16}$ ?) tożsamość, wybrać rodzaj tekstu dopasowanego do zadań stawianych przez wypowiadający chorobę podmiot. Sontag postanowiła uchylić się od mówienia o własnej chorobie i o sobie jako chorej, ale przywoływane przez nią liczne teksty literackie wcale od przenośni nie stronią, podobnie jak i ona sama nie ogranicza się do komunikacji somatycznej, biologicznej informacji czy medycznej dosłowności ${ }^{17}$. Zastanawia, że dana choroba, ta, na którą sama autorka zapadła, poddana metaforyzacji niejako automatycznie miałaby jej zdaniem generować stereotypowe rozumienie, prowadzić do uprzedzeń, odwodzić od terapii, naznaczać, wykluczać, okaleczać tożsamość. Wydaje się, że i Sontag z trudem przychodzi godzić umysł z ciałem, a przez to z językiem odnoszącym się do przygód ciała, i dlatego odmawia - ciału czy językowi? - prerogatywy przenośni.

\section{Metafora w interakcyjnej teorii Blacka}

Sontag zdaje się postrzegać metaforę zgodnie z definicją Arystotelesa, jako przeniesienie nazwy jednej rzeczy na inną̨ ${ }^{18}$ : metafory tworzymy po to, by "nadawać nazwę rzeczom nieposiadającym własnej nazwy"19 a ich użycie, uzależnione od zdolności dostrzegania podobieństw w rzeczach niepodobnych i z poszanowaniem zasady stosowności $\mathrm{ci}^{20}$, , uchroni język poetycki od pospolitości i przyziemności"21. Kognitywiści traktują przenośnie jako jeden z mechanizmów poznawczych, który realizuje się w języku. Metafora

Zob. S. Sontag Choroba jako metafora, s. 97, i E. Goffman Piętno: rozważania o zranionej tożsamości [1963], przeł. A. Dzierżyńska, J. Tokarska-Bakir, Gdańskie Wydawnictwo Psychologiczne, Gdańsk 2005. Choroba stygmatyzuje wtedy, kiedy nazywamy kogoś chorym, pomijając wszystkie inne cechy tej osoby.

M. Janion zauważa, że „odmitologizowanie choroby prowadzi u Sontag do całkowitej medykalizacji", tejże Osoby, wybór, oprac. i red. M. Janion i S. Rosiek, Wydawnictwo Morskie, Gdańsk 1984 , s. 365 .

\section{S. Sontag Choroba jako metafora, s. 87.}

Arystoteles Retoryka, III, 1405a, 30. Retoryka; Poetyka; przeł. H. Podbielski, PIW, Warszawa, 1988.

Arystoteles Poetyka, 1859a, 10. Retoryka; Poetyka; przeł. H. Podbielski, PIW, Warszawa, 1988.

Arystoteles Poetyka, 1458a, 33. Retoryka; Poetyka; przeł. H. Podbielski, PIW, Warszawa, 1988. 
to sposób rozumowania i zasada naszego doświadczania świata. Często nie zdajemy sobie sprawy z jej stosowania, choć nie możemy się bez niej obejść. O ile zrozumienie konwencjonalnej metafory pozwala uchwycić złożoność wypowiedzi poetyckiej, o tyle ujęcie kognitywne oferuje możliwość dotarcia do fundamentów systemu pojęciowego, na którym zasadza się nasz sposób postrzegania świata zewnętrznego i wewnętrznego. Metaforycznie nie tylko mówimy, przede wszystkim metaforycznie myślimy ${ }^{22}$.

Współczesne teorie metafory zrodziły się na gruncie filozofii analitycznej. Przypomnieć należy zwłaszcza zastępującą teorie substytucji i analogii interakcyjną teorię Maxa Blacka, zgodnie z którą domeny, „filtr” i „ekran”, przedmiot podstawowy i wtórny czy "nośnik” (vehicle) i „temat” (tenor), wzajemnie na siebie oddziałują. Metafora rzadko działa jako zwykły substytut, jest twórcza (Black przywołuje Coleridge'a ${ }^{23}$ ), a jej autorzy naruszają zastane reguły i generują nowe znaczenia. Twórca wypowiedzi metaforycznej „selekcjonuje, uwypukla, zaciera i organizuje cechy przedmiotu podstawowego, odnosząc do niego stwierdzenia izomorficzne z członami zespołu implikacji przedmiotu wtórnego"24. Metafora nie tylko odkrywa, wydobywa czy formułuje podobieństwo już istniejące, lecz je st wa rza. Twórczy charakter tej figury czyni ją „instrumentem poznania”, niezbędnym „do dostrzeżenia związków, które, raz dostrzeżone, stają się n a s tę p n i e rzeczywiście związkami” ${ }^{25}$, co oznacza, że potrafi ona przekształcać myślenie, przesuwać znaczenie którejś $\mathrm{z}$ domen, kierować rzeczywistość na inne tory.

W klasyfikacji Blacka na uwagę zasługują zwłaszcza metafory emfatyczne (a przykładem metafory mocnej wydaje się właśnie poważna choroba), niedające się zastąpić czy zredukować do roli ozdobnej, „upiększającej”, mające „zastanawiać i zaciekawiać swymi niewyrażonymi implikacjami”. Ich twórcy wymagają od odbiorców „współdziałania w rozumieniu tego, co kryje się za słowami, których użyto", a to, , jak daleko może posuwać się taka interpretacja odbiorcza, zależy od możliwości tkwiących w danym temacie metafory"26.

G. Lakoff, M. Johnson Metafory w naszym życiu, przeł. T.P. Krzeszowski, PIW, Warszawa 1988.

Tezy zawarte w Metaphor („Proceedings of the Aristotelian Society” 1954-1955 N.S., S. 273-294) filozof reasumuje w: More about metaphor, "Dialectica” 1977 no. 31, s. 43-57. Polski przekład: M. Black/eszcze raz o metaforze, przeł. M.B. Fedewicz , "Pamiętnik Literacki” 1983 z. 2, s. 264-281, tu s. 259.

Tamże, s. 266.

Tamże, s. 278.

Tamże, s. 264. 
Black zwraca też uwagę na fakt, że tworząc wyrażenia metaforyczne, używamy „ramy pojęciowej” (assumptive framework) pozwalającej filtrować informacje, które wydają się nam zbędne, i skupiać na tym, co uznajemy za istotne. Posługując się wyrażeniem metaforycznym, obcujemy z tajemnicą polegającą na tym, że mówiący utrzymuje, że coś jest czymś, czym nie jest, i prowokującą m.in. pytania, takie jak: jeśli rzecz zastępuje się inną rzeczą, to dlaczego tą, a nie inną i jakie są implikacje danych wyrażeń metaforycznych? Sam zaś fakt, że myślimy metaforycznie, wynika z tego, że możemy (granice pojęć są rozciągliwe i przenikalne), często musimy (dosłowne możliwości języka są niewystarczalne) i chcemy, bo w metaforze zawierają się taki wgląd w rzeczywistość i rozumienie świata, jakich nie można osiągnąć inaczej ${ }^{27}$. Z teorii interakcyjnej Blacka korzystam, uzupełniając ją o spostrzeżenia dotyczące przesunięcia znaczeń, które następuje na skutek krzyżowania domen i ich implikacji, kiedy chorobę lokujemy raz w domenie źródłowej, a kiedy indziej w domenie docelowej metafory.

\section{Ukoić wyobraźnię chorego?}

Sontag przeciwnie, przywołując Jutrzenkę Nietzschego, pragnie „ukoić wyobraźnię chorego, by przynajmniej, jak to działo się dotychczas, nie cierpiał [on] więcej skutkiem rozmyślania nad swą chorobą, aniżeli wskutek choroby samej"28. Krytyczka zwraca uwagę na figuralne wykorzystanie choroby („metafory i mity zabijają”), które przyczyniać się ma do zwiększenia cierpienia chorego potencjalnie zniechęcanego do wczesnej kuracji lub do podjęcia większych wysiłków celem znalezienia kompetentnej pomocy, i przekonuje, by chorzy i ich opiekunowie „uważali raka po prostu za chorobę - bardzo poważną, lecz tylko chorobę. Nie za przekleństwo, nie za karę, nie za powód do wstydu. Za coś, co nie ma ukrytego znaczenia"29. Zarazem sama popada w niekonsekwencję (kiedy pisze o chorobie jako o nocnej stronie życia, a dekadę później tłumaczy ów fragment jako żartobliwy egzorcyzm metaforycznego myślenia ${ }^{30}$ ) i dokonuje autobiograficznego

27 Tamże, s. 272.

S. Sontag Choroba jako metafora, s. 95.

Tamże, s. 96. 
wyparcia (nie chce pisać o sobie i o swojej chorobie onkologicznej), jakby kierował nią lęk przed własną kruchością, którą odsłoniła przed nią choroba. Odkrycie to jest wyzwaniem o wiele większym niż odkrycie cudzej słabości. Być może w geście obrony własnego „ja” przed tą nieakceptowaną kruchością zadziałał z całą gwałtownością mechanizm przeniesienia i dlatego winą ${ }^{31}$ należało obarczyć kogoś/coś innego: już nawet nie samą chorobę - tę można zawsze „zmedykalizować” - lecz figuralny język, którym posługujemy się od wieków. Perspektywa przyjęta przez Amerykankę sugeruje, że to metafora, nie choroba, jest źródłem cierpienia, a wówczas pisanie - źle - o metaforach choroby zastępuje w jakimś sensie pisanie o chorobie i uwalnia Sontag od złości i gniewu, lęku i rozpaczy, które, jak pisze, odczuwała, kiedy przebywała w szpitalu jako pacjentka onkologicz$\mathrm{na}^{32}$. Jeśli istotnie chorego uciska nie biologia/fizjologia, lecz kultura/język („reputacja [...] choroby zwiększa cierpienie chorych" ${ }^{33}$ ), jeśli poddamy nasz metaforyczny język egzorcyzmom ${ }^{34}$, to czy wówczas cierpienie wywołane chorobą ma szansę się zmniejszyć? Czy na skutek choroby język ulega zakażeniu, a podmiot tracący zdrowie traci dostęp do owej szczególnej potencji czy dyspozycji języka, jaką jest tworzenie metafor? Użycie przenośni, za sprawą których chory podlega stygmatyzacji, z pewnością może stać się dodatkowym, ale nie zasadniczym źródłem cierpienia związanym $\mathrm{z}$ chorowaniem.

Przenośnia jednak należy do opowieści o chorobie (a metafory działań wojennych ${ }^{35}$, na które zżyma się Sontag, należą do języka maladycznego

„Sans-papier, kogoś bez paszportu do świata choroby". Tekst na okładce wierszy A. Bertoniego Ricordi di Alzheimer, Book Editore, Ro' Ferrarese 2008.

31 W rozdziałach 5 i 8 eseju Choroba jako metafora Sontag przywołuje inspirowane psychologizmem W. Reicha przekonanie o winie chorego i o chorobie jako karze.

Tamże, s. 93.

Tamże.

Tamże, s. 87.

W posłowiu do włoskiego przekładu eseju V. Woolf O chorowaniu N. Gardini zwraca uwagę na kontekst, w jakim Sontag pisała esej Choroba jako metafora, i podkreśla, że ukrytym celem jej ataku był amerykański imperializm. Posługując się krytyką metafor wojennych, Amerykanka kwestionowała propagandę polityczną konserwatystów. Por. N. Gardini Postfazione, w: V. Woolf Sulla malattia, Bollati Boringhieri, Torino 2006, s. 68-80, tu s. 70. Jak podaje Sontag, chorobę jako wroga dokonującego inwazji na fortecę ciała pierwszy ukazał John Donne w Devotions Upon Emergent Occasions (1627). Metafora wojskowa rozprzestrzeniła się po tym, jak poznaliśmy drobnoustroje. 
w sposób szczególny) na tych samych prawach, co jest figurą języka i narracji w ogóle czy - jak zakładają kognitywiści - stanowi schemat naszego myślenia, rozumienia i działania w ogóle. Można by sądzić, że w czasie choroby nadawca tekstu tym chętniej wkracza na teren metafory, peryfrazy, synonimu, im mniej o danej chorobie wiadomo ${ }^{36}$, im bardziej jest ona niezbadana i w większym stopniu nieuleczalna, a dla samego cierpiącego uciążliwa. Być może skłonność do pseudonimowania choroby rośnie, gdy w jej przebiegu zostają upośledzone funkcje, kompetencje i zdolności, które współczesna kultura ceni najwyżej (produktywność, samowystarczalność, autonomia), co oznaczałoby, że szczególnie podatne na metaforyzację będą współczesne choroby neurodegeneracyjne. Że to metafory, a nie ich brak, koją wyobraźnię chorego, widać w Dziennikach Jerzego Pilcha, będących zapisem cierpienia wywołanego chorobą Parkinsona, zapisem skorygowanym przez taktykę rozbrajania i ujarzmiania choroby za pomocą rozmaitych środków językowych, w tym przenośni ${ }^{37}$. Narrator Żywego ducha - tu pisarz posługuje się apokalipsą jako figurą Parkinsona - doświadcza choroby jako końca (znanego mu) świata i kresu możliwości życia tak jak wcześniej. Przeżywa kres możliwości myślenia i planowania przyszłości. Metafora choroby rozrosła się i zawładnęła wyobraźnią narratora i całą opowieścią. Nadzieja na życie po końcu świata odrodziła się po wszczepieniu baterii DBS, kiedy chory zdołał już się ze światem pożegnać. Przeżył, zupełnie sam, a samotność w opustoszałej po katastrofie rzeczywistości to idealna sytuacja, by zastanawiać się nad wartością życia, świata i naszego w nim istnienia. Nie sposób zgłębić tajemnicy apokalipsy, a na prawach przenośni - tajemnicy choroby. Można wszak zagadkę zagadać' ${ }^{38}$. Pisząc,

36 We współczesnych patografiach wyszedł z użycia jeden z najstarszych toposów narracji o chorobie i cierpieniu: topos niewyrażalności typowy dla The Mystery of Pain Emily Dickinson.

37 W ironiczny nawias ujmuje też Pilch esej Sontag: „Kogo nie da się wykluczyć - tego należy zignorować, upokorzyć, sterroryzować, zaszczuć. Jedyne wyjście? Może nie jedyne, ale dla mnie wymarzone. Cykl tekstów polemizujących z chorobą, miażdżących chorobę, kompromitujących chorobę, wykazujących chorobie elementarne braki, doprowadzających chorobę do skrajnej depresji, cykl jadowitych pamfletów pod przewodnim tytułem: Choroba na równi pochyłej, to mój sen, moje marzenie i moja nadzieja; za możliwość napisania takiej rzeczy zrobię, Panie Boże, wszystko, dziecku - jeśli każesz - wyrwę z zaciśniętej piąstki ostatnią landrynkę", Drugi dziennik, 21 czerwca 2012-20 czerwca 2013, Wydawnictwo Literackie, Kraków 2013, s. 205. wa temat, a literacki fach daje możliwość zmierzenia się z "neurologiczną entropią", zob. tejże Dziwne światło, "Magazyn Literacki. Książki w Tygodniku” 2012 nr 3-4, s. 9. Choroba jako zjawisko tekstotwórcze to jeden z najczęstszych toposów patografii, których moc absolutyzuje 
cierpiący buduje dystans, próbuje przechytrzyć chorobę. A to jest przecież strategia literacka o znaku przeciwnym do Sontag. Doznawszy katastrofy choroby, narrator Pilcha poszukuje języka, który zetknie go z wyobcowującym się w jej przebiegu ciałem. Zabawne peryfrazy i porównania pomagają osłabić demona choroby:

Nie ma najmniejszego powodu, by choroba nie przypominała dobrze opowiedzianej historii. Rzecz jasna jakieś patetyczne dyrdymały o rzemiośle, które ocala - darujmy sobie. Nic nie ocala. Owszem, choroba nie lubi, jak o niej piszesz... [...] Opisane słabnie, [...]; zapisz, zapisz i przestać o tym myślećs ${ }^{39}$.

\section{Nowa szkarłatna litera „A"}

W eseju o AIDS, o dekadę późniejszym od polemiki z aparatem interpretacji, stereotypów i znaczeń moralnych, które osadziły się na chorobach, obciążyły je społecznymi uprzedzeniami, a w chorych wywołały poczucie winy i zmniejszyły ich szanse wyzdrowienia, Amerykanka napisze, że choć pewne przenośnie należałoby odesłać na zasłużony odpoczynek, „oczywiście nie sposób myśleć bez metafor"40. Jej wysiłek opisywania rzeczy bez nadawania znaczeń nie przyniósł rezultatów, co potwierdza dobitnie właśnie ów drugi esej. Rak ukazany we wcześniejszym eseju traci swoją metaforyczną moc tylko dlatego, że zostaje zdetronizowany przez inną chorobę, skuteczniej tworzącą tożsamość ułomną: „Wydaje się, że społeczeństwo musi mieć chorobę, która staje się tożsama ze złem oraz obciąża odpowiedzialnością swoje ofiary, choć najwyraźniej trudno nam zaprzątać

A. Frank. Wyróżnia on trzy odmiany patografii: restytucji, chaosu i poszukiwania; por. tegoż The Wounded Storyteller, Chicago U.P., Chicago 1995. Broyard pisze: „W sytuacjach skrajnych zawsze tworzymy narracje. Opisujemy to, co się dzieje, jakbyśmy chcieli zapobiec katastrofie. [...] Opowiadanie historii wydaje się naturalną reakcją na chorobę. Ludzie krwawią historiami, a ja stałem się ich bankiem krwi”; „Bo dla człowieka ciężko chorego otwarcie się przed innymi jest jak upuszczanie krwi"; "Moje laboratorium to literatura, w niej odnajduję lekarstwo na wszelkie niedogodności", Upojony choroba, s. 35, 37, 44. W patografii dementywnej T. DeBaggia, u którego w wieku pięćdziesięciu lat stwierdzono otępienie alzheimerowskie, pisze: „Zdecydowałem, że książka jest ważniejsza. [...] Lepiej radziłem sobie ze słowami niż z lekarzami i badaczami", Losing My Mind, The Free Press, London-Toronto-Singapore-Sydney 2002, s. 31. 
sobie uwagę więcej niż jedną taką chorobą"41. Wszyscy (nie tylko pacjenci, jak twierdzi Sontag ${ }^{42}$ ) najbardziej boimy się zubażającego nas cierpienia. Do rangi najstraszniejszej, bo najbardziej degradującej choroby naszych czasów - która wywołuje wstyd, upokorzenie, dehumanizuje, odbiera tożsamość, pamięć i nie daje żadnej mitologii kompensacyjnej (jaką dawały np. romantyczne suchoty ${ }^{43}$ ) - awansował tymczasem alzheimer, nowa szkarłatna litera "A"44.

Fakt, że od owych degradujących metafor choroby, czyli od choroby jako domeny docelowej, Sontag przechodzi płynnie do choroby jako domeny źródłowej, metafory opisującej inne negatywnie oceniane zjawiska ${ }^{45}$, ów brak rozróżnienia między domenami stanowi dla mnie zachętę do oznaczenia implikacji dwubiegunowego przyporządkowania figur choroby otępiennej. Opiszę wpierw kilka metafor, w których demencja jest domeną źródłową (w terminologii Blacka - nośnikiem), tj. dostarcza środków do mówienia o czymś innym. Zgodnie z założeniami lingwistyki kognitywnej na podstawie analizy takich metafor można odtworzyć sposób postrzegania przez społeczność użytkowników danego języka zjawisk ujętych jako domeny metafory.

Tamże, s. 97.

42 Tamże, s. 118.

Zob. rozdział 2 eseju Choroba jako metafora Sontag i opracowanie M. Szuberta Żyjąc w cieniu śmierci. Kulturowy obraz gruźlicy, Polskie Towarzystwo Ludoznawcze, Wrocław 2011.

Potwierdza to ranking chorób w wielu tekstach ostatnich lat. Dotknięta wczesną formą demencji bohaterka Motyla L. Genovej (przeł. Ł. Dunajski, Filia, Poznań 2014) stwierdza, że w jednej chwili zamieniłaby swojego alzheimera na raka, wylew, paraliż. Nie musiałaby się wtedy wstydzić. Brat narratora autobiograficznej powieści Michaela Ignatieffa Scar tissue (Farrar, Straus, and Giroux, New York 1993) zastanawia się, co gorsze: stracić ciało i zachować umysł, jak chorzy na stwardnienie zanikowe boczne, tkwić w sercu katastrofy biologicznej, ale nie móc wyrazić, jak i co się wtedy czuje, myśli, czy może, jak ich cierpiąca na otępienie matka, stracić umysł w sytuacji, gdy ciało - przynajmniej przez jakiś czas - dalej funkcjonuje.

W tekście Sontag choroba - rak - w roli domeny źródłowej oznacza m.in. szkody wyrządzone przez nas środowisku naturalnemu, które mści się na stechnicyzowanym i zindustrializowanym świecie. Metafory ekonomiczne i urbanistyczne raka wskazują na chaotyczny, nieograniczony i patologiczny wzrost/rozrost. W sferze politycznej metafora choroby, zwłaszcza raka, zastąpiła język religijny i filozoficzny, który nie potrafi już wyrażać zła (rak toczący nasze społeczeństwa to zdaniem niektórych imigranci, przedstawiciele innych narodów, religii, stylów życia, orientacji). 


\section{Demencja jako nośnik metafory kulturowej}

Pierwsza o chorobie otępiennej jako domenie źródłowej częstej obecnie metafory kulturowej pisała Hannah Zeilig ${ }^{46}$, twierdząc, że demencja to figura kondycji człowieka we współczesnym świecie. Kojarzona z sytuacją straty i umniejszenia (loss and diminishment) służy do opisu nas samych, naszego społeczeństwa, życia, które stało się absurdalnie zabiegane/zajęte. Stefano Tani przekonuje, że demencja jest wynikiem stresu wywołanego działaniem ekranów, reakcją organizmu na przebodźcowanie, i atakuje najbardziej osobistą część człowieka, związaną z narracją, pamięcią, relacjami i funkcjonowaniem jako żywej i myślącej istoty ${ }^{47}$. Badacz wyobraża sobie otępienie jako zachowanie mózgu dążącego do uwolnienia się od nadmiaru informacji, ,kasującego” wiadomości. Zombie - figura pustki, próżni - lepiej oddaje cierpiącego na chorobę otępienną niż figura wampira, czyli tego, który opróżnia. Tani inspiruje się najprawdopodobniej tezami Roberta T. Woodsa o żywym trupie czy Susan M. Behuniak o tym, że demencja to „śmierć wyprzedzająca ciało", zamieniająca człowieka w zombie. W jej wyniku dochodzi do obumarcia mózgu, który pozostawia za sobą żywe, ale pozbawione sprawczości ciało ${ }^{48}$.

Wracając do choroby otępiennej jako domeny źródłowej metafory, alzheimer jako soczewka wielu bolączek pojawia się w fenomenalnej powieści autobiograficznej Flavia Pagana Perdutamente. Na otępienie cierpi tu nie

46 H. Zeilig Dementia As a Cultural Metaphor, "The Gerontologist” 1 April 2014 Vol. 54 Issue 2, S. $258-267$.

47 S. Tani Lo schermo, I'Alzheimer, lo zombie. Tre metafore del XXI secolo, Verona, Ombre Corte 2014, s. 79, i tegoż La malattia degli schermi, w: Il primato delle tecnologie. Guida per una nuova iperumanità, ed. C. Bordoni, Mimesis, Milano 2020, s. 199-207, tu s. 206. Słabym punktem analizy Włocha jest to, że choroba otępienna dotyka przeważnie osób starszych, raczej niebędących głównymi ofiarami stresu ekranowego. Tezie o utracie czy unicestwieniu, którego dokonuje choroba, sprzeciwia się C. Malabou. Zgodnie z koncepcją plastyczności mózgu i plastycznej tożsamości, chorując, stajemy się po części kimś innym, choroba to nowy początek. Destrukcja jest plastyczna, a jej proces oddziaływania na organizm można porównać do rzeźbienia. Granica między zdrowiem a chorobą nie jest ostra. C. Malabou Plastyczność a cierpienie mózgowe i psychiczne, przeł. M. Burzyk, "Znak" 2016 nr 4, s. 75. Zob. też B. Morzyńska-Wrzosek Odmrażanie nie-swojej obecności. Redefiniowanie tożsamości w narracjach o demencji, w: Fragmenty dyskursu maladycznego, red. M. Ganczar, I. Gielata, M. Ładoń, Fundacja terytoria książki, Gdańsk 2019, S. 127-143.

48 R.T. Woods Alzheimer's Disease: Coping with a Living Death, Souvenir, London 1989; S. Behuniak The Living Dead: Constructing Alzheimer's Patients as Zombies in the Euthanasia Debate , Ageing and Society" $2011 \mathrm{nr}$ 31/1, s. 70-92. Zob. też B. Pitt Psychogeriatrics: An Introduction to Psychiatry of Old Age, Churchill Livingstone, London 1982, s. 39: "Czasami wydaje się, że jaźń umarła na długo przed ciałem". 
tylko matka narratora, lecz cała polis. Neapol to miasto alzheimerowskie, locus chaosu i nieporządku, nazwane „najbardziej chwiejnym i alzheimerowskim miastem świata”" dzieją się w ułamku sekundy (najczęściej odwrotnie niż oczekiwaliśmy)"50. Demencja poddana uproszczeniu (bo wyrażenie metaforyczne, pisał Black, zwraca uwagę na pewne aspekty przedmiotu, skupia uwagę na wybranych elementach choroby, ignorując czy ukrywając pozostałe) wskazuje często na amnezję historyczną. Staje się figurą wyparcia minionych zdarzeń, zwłaszcza tych kłopotliwych, wciąż nierozliczonych, jak w wierszu Andrei Zanzotta De senectute, mówiącym o „ciężkim zapomnieniu” społeczeństwa dotkniętego chorobą neurodegeneracyjną ${ }^{51}$.W Tristissimi 25 aprile (Smutne święta wyzwolenia) poeta kojarzy demencję ze zjawiskiem zbiorowej amnezji, zapominaniem niektórych „smutnych rocznic": „starzy partyzanci / gubią się / z tym ich alzheimerem / dawni więźniowie / w tym ich stanie po wylewie / wszystko stracone" 52 . Nasze „ultrademencje” wywołały też dziką urbanizację, poddały mafijnej władzy przemysłowe peryferie. W powieści Awrahama B. Jehoszuy ${ }^{53}$ demencja jest nośnikiem rozbudowanej metafory politycznej, konfliktu izraelsko-palestyńskiego. Zapomnienie dotyka niedawnej historii, Davida Ben Guriona, Żydów, którzy nie pamiętają już, kim są, Palestyńczyków, którzy przestali być Palestyńczykami, nie stając się Izraelczykami, przesuwających się granic, przybranych imion, tożsamości w tranzycie. Alzheimer dobrze oddaje też złożoność współczesnego świata w powieści Arna Geigera, który pisze:

świat jest zagmatwany i kiedy spojrzeć na to trzeźwym okiem, widać, że różnica między zdrowym a chorym człowiekiem polega przede wszystkim na tym, w jakim stopniu potrafi on utrzymać jakiś ład na powierzchni. Choć pod spodem szaleje chaos. Także dla względnie zdrowych ludzi porządek w głowie jest jedynie rozsądną fikcją. Nam, zdrowym, choroba Alzheimera pozwala dostrzec, jakich złożonych umiejętności potrzeba, by podołać codziennemu życiu. ${ }^{54}$

F. Pagano Perdutamente, s. 67.

Tamże, s. 82.

A. Zanzotto De senectute, w: tegoż Conglomerati, Mondadori, Milano 2009, s. 67-68.

Tamże, s. 41-42.

A.B. Yehoshua The Tunnel, transl. by S. Schoffman, Houghton Mifflin Harcourt, Boston, 2020.

A. Geiger Stary król na wygnaniu, przeł. K. Niedenthal, Świat Książki, Warszawa 2013, s. 57-58. 
Skoro demencja odzwierciedla stan społeczeństwa, w którym nie sposób już utrzymać się na powierzchni zdarzeń, dotrzymać kroku postępowi i przyrostowi informacji, nie dziwi, że tajemnica spowijająca chorobę inspiruje autorów filmów i powieści z dreszczykiem ${ }^{55}$. Zagadka choroby o tajemniczym przebiegu i wciąż nieznanej etiologii okazuje się godna zwłaszcza czarnego kryminału, który strukturalnie ma z demencją wiele wspólnego. $\mathrm{Na}$ ich analogie wskazują takie cechy przebiegu otępienia, jak: wątpliwości tożsamościowe, tajemnica powolnego znikania, utrata przeszłości, siebie, języka i świata, a także fakt, że „sprawca” pozostaje nieznany. Teksty tego typu, poddając próbie kognitywne zdolności odbiorcy, uczą „oswajać” lęki, pomagają zwalczać stereotypy, pokazują, że demencja może odsłaniać przed nami większe prawdy. Skłaniają także do krytycznej refleksji nad dręczącym Sontag postrzeganiem choroby jako kary za winę czy zbrodnię („z pozoru winowajcą jest choroba. Chorych czyni się jednak współwinnymi"56), związkiem ulegającym w tekstach detektywistycznych znaczącemu rozluźnieniu. Demencja - choroba o wciąż niepewnej etiologii - raz wskazuje pragnienie zapomnienia doznanego cierpienia bądź popełnionej zbrodni, kiedy indziej każe podważać winę i podaje w wątpliwość nie tylko motywy, lecz także sam fakt popełnienia zbrodni. Metafora otępienna wskazuje na niepoznawalność przedstawianego w kryminałach świata, a zagadki detektywistyczne wprawiają w ruch katalog cech kojarzonych z demencją.

\section{Demencja w funkcji domeny docelowej}

O chorobie w sposób „pewny” - tzn. zgodny z aktualnie obowiązującą nozologią - można wypowiadać się wyłączenie z perspektywy biomedycznej. Ta jednak niewiele mówi o tym, jak doświadcza choroby cierpiący na nią człowiek. Toposowi zniewolenia chorobą ${ }^{57}$ dotrzymuje kroku równie popularnie

55 Zob. H. Serkowska D.D. jak dreszcz demencji, „Poznańskie Studia Polonistyczne. Seria Literacka” $2018 \mathrm{nr} 34$ (54), s. 41-62. Do omówionego tam katalogu dzieł z dreszczykiem i motywem demencji dodać można ostatnią część serii H. Mankella z komisarzem Wallanderem zatytułowaną Niespokojny człowiek (przeł. B. Walczak-Larsson, W.A.B., Warszawa 2010), w której cierpiący na demencję słynny detektyw schodzi ze sceny, oraz kryminały I. Tuti, w których pomimo rozwijającej się choroby otępiennej detektyw Teresa Battaglia kontynuuje poszukiwania sprawcy (Kwiaty nad piekłem, przeł. L. Rodziewicz-Doktór, Sonia Draga, Katowice 2019, i Śpiq̨ca nimfa, przeł. J. Kluza, Sonia Draga, Katowice 2020. 
występująca figura deficytu, braku, utraty, a obok niej - wygnania, banicji, wydziedziczenia ${ }^{58}$. W przypadku jednostek pozbawionych pewnej nozologii tropienie metafor, w których alzheimer występuje w funkcji domeny docelowej, daje bliskim chorego, a także lekarzom i opiekunom, wgląd w przeżywanie choroby i pozwala czerpać o niej wiedzę ze zindywidualizowanych zapisów jej przebiegu. Anatole Broyard pisze, że jego choroba onkologiczna do tego stopnia wyrwała go ze znanego mu świata, rzucając w nieznane, że zdawało mu się, iż romansuje z kobietą owładniętą demencją: domagała się od niego rzeczy, jakich jeszcze nigdy nie robil ${ }^{59}$. Aby choroba w ogóle mogła zostać skutecznie i wiarygodnie zakomunikowana i zrozumiana przez odbiorców, wymaga własnego stylu, zindywidualizowanego języka opisu. Zdaniem Woolf potrzebujemy języka nowego, ,pierwotniejszego, bardziej zmysłowego, bardziej wulgarnego"60. Takie zindywidualizowane zapisy "powszedniego dramatu ciała" (choroba bowiem, jak chce Woolf, jest wielkim konfesjonałem promującym dziecięcą szczerośćc1) mogą skutecznie rozbrajać i korygować fantazmaty konstytuujące się na przeciwległym biegunie, tj. na biegunie kulturowych wyobrażeń o chorobie w domenie źródłowej. Także przedstawiciele zawodów medycznych zmuszeni są przejść na stronę metaforycznych opisów choroby, kiedy wiedza biomedyczna jest niewystarczająca. Dzięki takiej poszerzonej o tropy anamnezie zyskują wgląd w to, jak chorobę rozumie i przeżywa pojedynczy pacjent. W przebiegu otępienia typu alzheimerowskiego sytuacja jest jeszcze bardziej złożona, bo cierpiący w krótkim czasie traci zdolność mówienia, a zatem także możliwość zdania osobistej relacji z cierpienia ${ }^{62}$.

58 Zob. M. Okupnik W niewoli ciała. Doświadczenie utraty zdrowia i jego reprezentacje, Universitas, Kraków, 2018.

59 A. Broyard Upojony chorobq, s. 36. Relacja Broyarda z choroby onkologicznej jest rewersem postawy Sontag: „Rozumiem teraz, dlaczego tak upodobali ją sobie romantycy: człowiek chory widzi wszystko jako metaforę. [...] muszę przyjmować lekarstwa i przystać na tę metaforykę", A. Broyard Upojony chorobq, s. 21. Odjęcie metafor językowi maladycznemu oznacza skazanie cierpiącego na milczenie lub na biomedyczny opis patologii językiem Hemingwaya (tamże, s. 21). Metafory w chorobie są jego zdaniem niezbędne. Dają pacjentowi poczucie komfortu jak własny szlafrok i kapcie.

V. Woolf, O chorowaniu, s. 31-32.

Tamże, s. 34 .

62
Zob. I.M. Krüger-Fürhoff Narrating the Limits of Narration. Alzheimer's Disease in Contemporary Literary Texts, w: Popularizing Dementia. Public Expressions and Representations of Forgetful- ness, ed. A.M.C. Swinnen, M. Schweda, transcript Verlag, Bielefeld 2015, s. 89-108. 
Pomocne stają się wówczas relacje bliskich i opiekunów chorego, oparte na więzi i obserwacji.

Niespecyficznymi nośnikami demencji są częste w obrazowaniu chorób w ogóle figury morskiej podróży, niewoli czy wojny i walki ${ }^{63}$. Na ich tle wyraźnie rysuje się specyficzny w opisie doświadczenia choroby otępiennej topos śniegu. Obecny w tytule zbioru opowiadań Clary Obermüller Es schneit in meinem Kopf. Erzählungen über Alzheimer und Demenz (W mojej głowie pada śnieg. Opowieści o chorobie Alzheimera i demencji), powraca obsesyjnie w wierszach Roberty Dapunt Le beatitudini della malattia (Błogosławieństwa choroby) ${ }^{64}$. Zdanie „I znowu śnieg” zamyka wiersz Il lavacro (Obmycie) ${ }^{65}$. W La sedia (Krzesło) czytamy: „zastanawiałaś się kiedyś, czy tam, gdzie kończy się śnieg / rosną trawy szczęśliwsze?"66. Śnieg w Della primavera (O wiośnie) pojawia się na progu wiosny, kiedy zwykle oczekujemy odradzającego się życia ${ }^{67}$. W wierszu Dell'infeconda voce (O jałowym głosie) Dapunt notuje:

Pragnę [...] pokryć się nieskończonym śniegiem. Białej kołdry objęcia chronią przed zimnym rozumowaniem.

Otworzyć usta i pozwolić, by śnieg padał mi do środka [...], by mnie wypełniał. [...] zaśnieżone moje wnętrze jest jak zewnętrze stoję nieruchoma.

Chcę się unieskazitelnić. Na zawsze zamilknąć,

63 J. Domaradzki (Medycyna i jej metafory. O roli metafor w komunikacji lekarz-pacjent, „Kultura i Edukacja" 2015 nr 3 (109), s. 27-46, tu s. 32) podaje, że metafora walki i wojny, silnie zakorzeniona w kulturze Zachodu, poza medycyną jest przywoływana w wielu dziedzinach - od sportu, ekonomii i religii po politykę. M. Chojnacka-Kuraś analizuje polski dyskurs medyczny i ukazuje zalety zastąpienia domeny walki unikającą wartościowania domeną podróży, zakładającą dodatkowo swobodę wyboru, możliwość decydowanie o sobie i szukanie sensu życia; por. tejże Kiedy WALKA staje się PODRÓŻĄ. O przeobrażeniach metafor opisujących doświadczenie chorowania z uwzględnieniem typu i fazy choroby, "Prace filologiczne" $2019 \mathrm{nr}$ LXXIII, s. 33-48, tu s. 46.

64 C. Obermüller Es schneit in meinem Kopf. Erzählungen über Alzheimer und Demenz, Nagel \& Kimche, Zürich, 2006; R. Dapunt Le beatitudini della malattia, Einaudi, Torino 2013.

65 R. Dapunt Le beatitudini della malattia, s. 8.

66 Tamże, s. 15.

67 Tamże, s. 37. 
przerwać sobie i milczeć. Zagrzebać się w sobie i zamrozić na zawsze dar „zwykłej mowy”.68

Pragnienie pogrzebania się w śniegu udziela się opiekunce chorej: „Mam w środku śnieg, zmrożone członki" ${ }^{\text {. }}$.Tak z kolei narrator Pieśni bełkotu Erwina Mortiera wyobraża sobie, że demencji doświadcza jego matka:

Dzisiaj w mocy śniło mi się, że spadło bardzo dużo śniegu i zrobiło się strasznie zimno, była mroźna noc, a ona chciała się bawić na dworze, w koszuli nocnej. Tańczyła w ogrodzie, boso, w śniegu, i ukryła się w pustym pniu drzewa. Powiedziała, że chce spać, i nie dało się jej stamtąd wyciągnąć, a cały czas robiło się coraz zimniej i ciemniej. ${ }^{70}$

Pierwszy jednak po figurę śniegu do opisu stanów dementywnych sięgnął w 1984 roku J. Bernlef w powieści Niewdzięczna pamięc ${ }^{c^{1}}$.Tu śnieg pojawia się co krok, począwszy od incipitu: „Może to przez ten śnieg już od rana czuję się taki zmęczony" (s. 7). Ślady psich łap na śniegu skrywają wszelkie zapachy (s. 6o), padający śnieg „zasypie wszystkie moje ślady” (s. 64). Także halucynacje przyjmują śnieżną formę: „nie chcę do tego człowieka na śniegu!” (s. 188), „wołanie, że znowu pada śnieg” (s. 191). Czyjś głos wznosi się i opada w rytm padającego za oknem śniegu, dopóki wiatr nie zakłóci równowagi między płatkami śniegu a głosem (s. 194). Wreszcie chory Maarten Klein zamyka oczy, śnieg sypie dalej: „Sypie nawet wewnątrz mnie. Znikąd już żadnej ochrony" (s. 195). Na tym przykładzie prześledzić możemy działanie mechanizmu interakcyjnego metafory: $\mathrm{z}$ domeny docelowej wybrane zostały te cechy, które zakładają uczucie pustki, zimna, zamarzanie i zamieranie. Stąd prawdopodobnie zrodził się pomysł, by próbując wyobrazić sobie, co dzieje się w głowie osoby cierpiącej na chorobę otępienną, sięgnąć po figurę śniegu. Domena śniegu zarazem, przy udziale innych swoich cech, takich jak czystość, nieskazitelność, może kierować uwagę użytkowników i odbiorców wypowiedzi na inne tory, sugerując tak odmienne od pierwszego rozumienie doświadczenia choroby otępiennej, jak uczucie ukojenia (bólu, lęku), uciszenia, wypełnienia.

68 Tamże, s. 21.

69 Tamże, s. 47.

70 E. Mortier Pieśni bełkotu. Mamine godzinki, przeł. Ł. Żebrowski, W.A.B. , Warszawa 2011, s. 189.

71 J. Bernlef Niewdzięczna pamięć, przeł. A. Oczko, Nasza Księgarnia, Warszawa 2010. 
W tekście Bernlefa, poświęconym w całości zapisowi doświadczenia alzheimera, znajdziemy także szereg wyrażeń będących realizacją metafory przedstawiającej demencję w dość popularnych kategoriach żeglarskich ${ }^{72}$ i wojennych. Na pytanie, jak się czuje, Maarten Klein odpowiada, porównując się do żaglowca, „który trafił na bezwietrzną pogodę. Potem znowu jest trochę wiatru, znów płynę. Świat ponownie ma na mnie wpływ i mogę się poruszać wraz z nim" (s. 94). Myślenie cierpi na chorobę morską (s. 97 i 115). Sposób, w jaki bohater doświadcza choroby otępiennej, opisywany jest dalej także przez nawiązania do wojny, okupacji, ruchu oporu, Zagłady ${ }^{73}$. Więź wojna-demencja jest dwustronna: demencja odblokowuje wspomnienia wojenne (w typowym przebiegu tej choroby wpierw zanika pamięć krótkoterminowa i pojawiają się reminiscencje, zwłaszcza traumatycznych doznań bohatera mającego za sobą udział w ruchu oporu) i może być pretekstem do wprowadzenia tematu wojny, a równocześnie bywa opisywana za pomocą odniesień do konfliktu wojennego i związanych z nim doznań oraz zjawisk takich, jak lęk, zagrożenie, ucieczka. Bernlef wykorzystuje traumę wojenną nie tylko do wzmocnienia przekazu o utracie pamięci (o zbrodniach przeszłości nie powinno się zapominać), lecz także jako główne pole semantyczne użyte dla zobrazowania sposobu, w jaki bohater doświadcza choroby, kiedy walka przenosi się do wnętrza jego ciała i umysłu. Autor zwiększa natężenie tych odwołań w miarę postępującej choroby. Marteen ma wrażenie, że wojna

72 W Stanqć na nogi (przeł. E. Mikina, Zysk i s-ka. Poznań 1999) O. Sacks buduje wpierw metaforę żeglarską: „Gdy użyłem określenia shipshape, poczułem się naprawdę niczym żaglowiec, żywy żaglowiec, statek życia, jakby moje ciało było okrętem, którym żegluję przez życie, a jego konstrukcja, podobnie jak zgodnie pracujący marynarze posłuszna jest komendom kapitana, którym jestem ja" (s. 45-46), by potem zdekonstruować ją jako wyraz utraty nadziei na wyzdrowienie: „Wizerunekżaglowca, z jego mocną konstrukcją, sprawnymi marynarzami i panującym nad całością kapitanem, obraz, który jeszcze rano tak żywo stał mi przed oczami, teraz nabrał cech horroru. Zamiast natrafić na przegniłą belkę, zamiast stwierdzić, że któryś z marynarzy jest głuchy albo niesubordynowany, widziałem, że ja, kapitan, nie jestem już kapitanem. Ja, kapitan, miałem uszkodzony mózg" (s. 53). O metaforze raka jako podróży morskiej pisze M. Okupnik. Choroba - samotny, niedobrowolny rejs - obejmuje motyw walki, ale w sensie sportowym, nie militarnym: chodzi o walkę z samym sobą, swoimi słabościami, oporem ciała; por. M. Okupnik, Wniewoli ciała, s. 168.

Choroba otępienna, utrata indywidualnej pamięci wywołują potrzebę ustanowienia świadka choroby, działającego w zastępstwie chorego testis czy auctor, kultywującego pamięć interpersonalną, a także depozytariusza pamięci o chorym. Postulat ten odpowiada tezom o reetykalizacji i otworzeniu kontekstu świadectwa na konteksty pozazagładowe sformułowanym przez M. Givoni w: The care of the witness: A contemporary history of testimony in crises, Cambridge U.P., Cambridge 2016. 
znów się zaczęła (s. 183), cierpi z powodu oblężenia, konspiracji, ukrywa się i odczuwa lęk przed nazistami oraz ulgę i radość, kiedy z pomocą przychodzą mu alianccy żołnierze (tak naprawdę doktor Eardli, s. 181). Kiedy karetka zabiera go do szpitala, mówi o deportacji (s.197), czuje, jak świecą mu do środka lampami, poszukują ukrywającego się w Maartenie Kleinie Maartena Kleina (s. 204). Słyszy ogień karabinów: „strzały... pięknie, więc ciągle wojna... czy ona nigdy się nie skończy?... okupowany od środka... zajęli mnie" (s. 209).

Dwa inne przykłady potwierdzają, każdy na swój sposób, tezę Megan-Jane Johnstone, że demencję mogą opisywać nośniki metaforyczne, takie jak epidemia (jakby demencja była zakaźna), katastrofy naturalne i wojskowa inwazja ze strony czegoś lub kogoś obcego ${ }^{74}$. Narrator Korekt Jonathana Franzena, mówiąc o zamęcie, jaki w głowie jego ojca Alfreda wywołuje choroba, o tym, jak zmieniają się relacje z opiekującą się nim żoną, posługuje się serią metafor militarno-wojennych, godnych eseju Sontag. Mowa o niespodziewanych nalotach, migracjach, deportacjach. Uciekinierzy i wrogowie, zmuszeni do podjęcia działań partyzanckich (w domu Lambertów życie zeszło do podziemia), zderzają się z niepotrafiącą już rządzić władzą ${ }^{75}$. W opowiadaniu Fusy Magdaleny Tulli narratorka opisuje demencję matki, posługując się metaforami katastrof naturalnych: „Pod koniec zawartość jej pamięci, zwłaszcza dalszych przegródek, zawierających fakty z dojrzałego życia, niszczała zrzucona na stertę, jak po trzęsieniu ziemi" ${ }^{776}$, i działań wojennych. Tu jednak przekształca obrazy starcia zbrojnego, jakie kreśliła Sontag77. Sięgając do tej samej wojennej domeny, zmienia implikacje wyrażenia metaforycznego. Obserwujemy nie batalię (chory unika cierpienia związanego z wyobrażaną metaforycznie walką w sytuacji, kiedy przegrywa lub nie potrafi jej podjaćc), lecz krajobraz po bitwie, zgliszcza, zniszczenia, opadający kurz:

M.-J. Johnstone Metaphors, Stigma and the "Alzheimerization" of the Euthanasia Debate, „Dementia" 2013 no. 12/1, s. 377-393, tu s. 390.

J. Franzen Korekty, przeł. J. Grabarek, A. Nakoniecznik, Świat Książki, Warszawa 2004, s. 12-13 i 17.

M. Tulli Fusy, w: tejże Włoskie szpilki, Nisza, Warszawa, 2011, s. 21-38, tu s. 29.

Sontag pisze o wygrywaniu lub przegrywaniu walki z chorobą, którą atakuje się lub przed którą się broni, w starciu z którą zdobywa lub traci grunt, tworzy plany i stosuje strategie, a jeśli znajdzie się pozycję nie do obrony, porzuca się ją i wybiera nową linię ataku (Choroba jako metafora, s. 171). Choroba jest wrogiem, komórki rakowe dokonują inwazji, atakują, niszczą, zakładają przyczółki i dokonują przerzutów. Walczy się z nimi, bombardując pacjenta zabójczymi promieniami, a chemioterapia to "wojna chemiczna z użyciem trucizn” (s. 65-66). Gorączka oznacza walkę, jaką podjął zaatakowany przez czynniki chorobotwórcze organizm. Na inwazję obcych ciał reagujemy, mobilizując bariery immunologiczne, (s. 9o). 
Jej choroba była jak schyłek imperium. Armie cofały się, opuszczały przyczółki zajęte w czasach minionej świetności, posągi kruszały, pałace zarastały zielskiem. Urzędnicy cesarstwa nie myśleli już o wielkości, tylko o przetrwaniu, to znaczy o tym, co najbardziej doczesne i najbliższe ciału, a przez opuszczone punkty graniczne przenikali obcy - wirusy, bakterie - i przejmowali rządy. ${ }^{78}$

Ze zgliszczy wyłania się coś wyzwolonego od myśli o zwycięstwie, o korzyściach, które niesie wygrana, a odbiera porażka. Uwagę skupiamy na tym, co jeszcze zostało. Przetrwanie cielesne wypiera obłożoną stygmatem utratę pamięci. Tabu, puste miejsce wśród medialnych obrazów - przywykliśmy do widoku okaleczonych ciał, ale telewizja rzadko pokazuje zdewastowany mózg - wyrażenie metaforyczne próbuje wypełnić nośnikami zmieniającymi rozumienie demencji. Z figur utraty i pustki stara się przejść ku temu, co przetrwało, podobnie jak opowiadająca się za perspektywą ucieleśnienia (embodiment) nowa gerontologia kulturowa ${ }^{79}$. Nowa perspektywa pozwala patrzeć na chorego jak na podmiot obdarzony tożsamością i ciałem zdolnym do autoekspresji, posiadający własny potencjał eksplorowania świata dzięki nawykom i zwyczajom często wpajanym lub nabytym indywidualnie (pamięć proceduralna, koordynacja motoryczna, percepcja zmysłowa świata, gesty, język ciała, odruchy społeczne).

We współczesnej kulturze alzheimer skupia w sobie i wyraża nasz lęk przed utratą kontroli nad własnym ciałem i umysłem, przed utratą siebie i świata. Staje się figurą akcentującą brak, podkreślającą deficyt. Cierpiących na otępienie pozbawia się udziału w społecznej wymianie, wyklucza, dehumanizuje. Wyzwaniem dla użytkowników języka jest unikanie tabuizacji i stygmatyzacji cierpiących i ich bliskich. Dzięki temu, że pokazując coś lub ukrywając metafory, potrafią zatrzeć pewien wątek, a rozbudować inny w formie implikacji metaforycznych, mogą np. prowadzić do przesunięcia uwagi $\mathrm{z}$ deficytu zwykle kojarzonego z demencją na to, co przetrwało, co jeszcze

78 M. Tulli Fusy, s. 22.

79 Tezę o rzekomej utracie sprawczości (agency), opartą na założeniu, że jedynie mózg określa nasze relacje ze światem i nadaje im znaczenie, podważyli T. Kitwood, K. Bredin Towards a Theory of Dementia Care: Personhood and Well-Being, "Ageing and Society" 1992 no. 12, s. 269-287, i P.C. Kontos Dementia and Embodiment, w: Routledge Handbook of Cultural Gerontology, ed. J. Twigg, W. Martin, Routledge, London-New York, 2015, s. 173-180. 
jest, oraz z perspektywy subiektywnej na relację, dzięki czemu chory unika uprzedmiotowienia i pozostaje (o) sobą.

Choroba w ogóle, w naszym przypadku alzheimer, potrafi zmieniać bieguny i odwracać rzutowanie. Raz jest domeną źródłową, a wtedy wydaje się nie wprowadzać nowej krwi do krwiobiegu naszego myślenia: uproszczona, stereotypizowana, bywa redukowana do jakiegoś modelu, często do negatywnie wartościowanej utraty pamięci (jednego z czterech A powszechnie kojarzonych z chorobą otępienną: amnezji, afazji, agnozji, apraksji). Takie metafory bywają krzywdzące dla osób dotkniętych chorobą i ich bliskich. Kiedy indziej demencja funkcjonuje jako cel: do opisu złożonego, trudno wyrażalnego doświadczenia choroby szukamy wówczas środków wyrazu. W tym zakresie metafora ma pewien potencjał innowacyjny, daje wgląd w istotę i przebieg demencji. Może też redukować, uwalniać od uprzedzeń widocznych w przeciwnym odwzorowaniu (alzheimer jako krytyczna metafora naszej kultury ceniącej racjonalny umysł, autonomię i samowystarczalność jednostki). Choroba staje się tu czymś złożonym, niejednoznacznym i wartym wyrażenia mimo wysiłku. Docenia sięją poprzez poszukiwanie domen, które będą w stanie ją przybliżyć.

\section{Abstract}

\section{Hanna Serkowska}

UNIVERSITY OF WARSAW

First of All, Stop Speaking in Metaphors! On the Tropes of Dementia

Serkowska examines the functions of metaphorical expressions in texts that belong to the maladic narrative current of the Alzheimerian variant. The point of departure is Susan Sontag's polemic with the notion of illness as a metaphor, but Serkowska also takes into account Max Black's interaction theory of metaphor and cognitive science. Her examples are texts where the key motif is dementia, describing the functions of the dementia-related metaphors as a source domain of metaphors and as a target domain.

\section{Keywords}

metaphor, source domain, target domain, dementia, Susan Sontag 